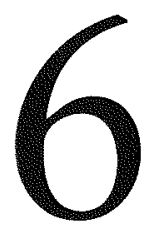

\title{
The recommendations on the electoral system: the contribution of the Fiji Constitution Review
}

\section{Yash Ghai}

In order to assess the electoral proposals of the Fiji Constitutional Review Commission (CRC), it is necessary to place them in the overall scheme of constitutional reform recommended by the Commission. The Commission states that its report is like a 'seamless document', whose component parts are inextricably linked and that 'its full import will be grasped only if it is read in its totality' (Fiji CRC 1996:3). This approach to the recommendations of the CRC is particularly important in view of the 'social engineering' orientation of its report, whereby constitutional rules are deliberately designed to achieve particular results (as opposed to, for example, a 'liberal' constitution which theoretically seeks merely to establish a 'political market place' where different ideas and options may be freely and equally pursued). Indeed a social engineering approach was required by the terms of its commission. It was the task of the CRC to recommend a constitution that would 'promote racial harmony and national unity and the economic and social advancement of all communities', paying attention to 'Fiji's needs as a multi-ethnic and multi-cultural society' (Fiji CRC 1996: 754-5).

The CRC decided that these goals would be best achieved through the emergence of multi-ethnic governments. The Commission also set out the broad framework within which a multi- 
ethnic government would be established. It supported the concept of the paramountcy of Fijian interests, so long as the concept was understood in its 'protective function' and did not 'involve the relegation of the interests of other communities'. It recommended that the Westminster parliamentary system should continue. At the same time the 'important role of the Bose Levu Vakaturaga', or Great Council of Chiefs, should be constitutionally recognised. The system of representation should move away from communal seats. There should be an increased role for backbench members of all parties. The Constitution should protect individual human rights and the rights of groups, including rights to land. It also recommended programs for social justice and affirmative action for the Fijian and Rotuman communities 'as well as for other disadvantaged communities and groups'. (These points are set out in chapter 2 of the report).

The rest of the lengthy and detailed report of the Commission sticks clearly and consistently to these objectives, and establishes a close connection between the various parts of its constitutional proposals. The report is admirably clear and well argued. It is by far the most sophisticated review of a constitution that has been undertaken in the South Pacific. However, there is not necessarily an internal coherence to its proposals. The role of the Bose Levu Vakaturaga and the constant emphasis on 'Fijian and Rotuman interests' (bracketed often with the 'interests of other communities'), the singling out of Christianity from other religions in Fiji in the proposed Preamble, and frequent genuflections to the paramountcy of Fijian interests are out of tune with its otherwise even-handed and humanistic approach. It would, however, be unfair to blame the Commission for these aberrations, for it was weighed down with the burden of history, and had to try to produce not only a fair set of proposals but also those which had some prospects of acceptance by the ruling élites in Fiji. Nevertheless, when assessing the proposals, these features cannot be ignored, since the report is a 'seamless web'.

\section{Proposals of the SVT and the NFP-FLP}

In order to understand and evaluate the recommendations of the $\mathrm{CRC}$, it is useful to provide a summary of the submissions of the major political parties. This will help to establish the ideas that were circulating in the country, the difficulties facing the Commission in 
establishing common ground, and insights into its own thinking in so far as it deviated from the submissions made to it.

The position of the Soqosoqo ni Vakavulewa ni Taukei (SVT) was that arrangements for power-sharing should be voluntary but made within a constitutional framework which recognised the political supremacy (and majority in parliamentary representation) of indigenous Fijians (SVT 1995:45). Otherwise it had little to say on coalitions or power-sharing, being concerned largely with castigating Indo-Fijians and accusing them of all manner of nefarious intentions and activities. Its general approach was scarcely that of a community looking for inter-racial cooperation and amity. Under its proposals, the decision whether to form a multi-ethnic party would effectively depend on the dominant indigenous Fijians' party, although that decision would be influenced by its strength in the legislature and consequently whether it had sufficient members to establish a government by itself. Nor did the SVT say much about the electoral system, but in so far as it wished to retain the 1990 Constitution, it supported a disproportionately large representation of indigenous Fijians and opposed any form of non-racial seats or parties. However, it was not clear how far this position represented the views of the leadership of the government, as it was rumoured that only a small group had drafted the submission and that it did not enjoy the support of some senior politicians. Certainly both its tone and content were at variance with the position adopted by ministers in their discussions with the opposition leading up to the establishment of the CRC and the drafting of its terms of reference.

By contrast, the position of the National Federation Party (NFP) and the Fiji Labour Party (FLP) clearly favoured a constitutionally mandated sharing of power. They had given much thought to the desirability and feasibility of power-sharing and constitutional provisions that would facilitate both a coalition type of government and its accountability to the legislature-which is reflected in their submission to the CRC (NFP-FLP 1995). The two parties claimed that the justification for some form of power-sharing at this stage of our history is overwhelming' (NFP-FLP 1995:54). They referred to the effect of the 1970 and 1990 constitutions of excluding a major ethnic group from any share in state power, or influence in its exercise, and argued that this had served to worsen race relations. They saw several advantages in power-sharing. 
Under it the cabinet would provide a framework for inter-ethnic negotiations and would facilitate the resolution of many outstanding problems of the country which requires accommodation of competing ethnic claims. It would ensure that no vital interests of any community would be disregarded. It would help to develop a national outlook on major issues facing us. It would lead to increased responsiveness to public needs. It would ensure greater stability in government and strengthen the party system. A particular advantage in Fiji would be that an agreement on power-sharing would facilitate an agreement on the electoral system - which is the most controversial decision your Commission would have to make-since every major community and party would be confident of participating in government and precise numbers of parliamentary seats would be of less moment than at present (NFP-FLP 1995:54).

Their submission also discussed possible shortcomings or negative consequences of power-sharing but considered that the 'advantages of power-sharing outweigh them-at least for now' (NFP-FLP 1995:55). However, in their proposals on power-sharing, they were concerned 'to maximise the advantages and minimise the drawbacks'. They realised that their proposals were not consistent in all respects with the Westminster system (although they were concerned to ensure that government remained accountable and that backbenchers would have an active role in policymaking and the supervision of administration). Their basic position was that the Westminster system as it had been constitutionally established and practised in Fiji had not served well the interests of the country.

The principal part of their proposal was that power-sharing should be constitutionally mandated, not voluntary. It would be inter-party rather than inter-ethnic. Any party which obtained more than 20 per cent of seats in the lower house would be entitled to a similar proportion of seats in the cabinet. The expectation clearly was that this proposal would result in leaders of all ethnic groups joining in government but also that it would not inhibit the development of inter-ethnic parties which might result from a formula which based power-sharing on ethnicity. Nevertheless, there would be an obligation on the part of the Prime Minister and the Deputy Prime Minister (drawn respectively from the largest and the second largest parties) to ensure a racially balanced cabinet (the minimum portfolios recommended were 40 per cent each for indigenous Fijians and Indo-Fijians and 5 per cent for others). 
The proposals of these parties on the electoral system were likewise determined by the objective of racial harmony and national unity-in contrast to previous systems which had 'pitted one community against another' (NFP-FLP 1995:57). The ultimate goal was non-communal voting of all members. However, as an interim measure, a certain number of communal seats would be retained. The recommendation was for 40 non-communal ('national') seats and 31 communal (14 each for indigenous Fijians and Indo-Fijians, and 3 for others). Communal seats would be elected from single-member constituencies on the alternative vote system to ensure a real majority, while the other seats would be contested on a system of Proportional Representation based on party lists, with the whole country as one constituency (with voters free to change the order of preference in relation to candidates of the party for which they vote). It recommended a threshold of seven per cent of the national vote in these elections before a party would become eligible for any seats.

The NFP and the FLP expected that the system of national seats would act as incentives towards the formation of non-racial or interracial political parties. There would be several incentives for the formation of such parties: national seats constitute the majority of seats; a party has to achieve seven per cent threshold to be eligible for a seat; a party qualifies for a seat in the cabinet only if it has at least 12 members in the legislature; and the largest party supplies the prime minister. It also recommended that no party would be allowed to contest elections unless its membership was open to all races.

\section{The Commission's approach to multi-ethnic government}

The Commission's assumptions about, and framework for, multiethnic government are quite specific. The first assumption is the retention of the Westminster system, which it regards as having served the South Pacific well (Fiji CRC 1996:22). Its scheme for multiethnic government had therefore to be fitted within the broad parameters of that system, which has not traditionally been hospitable to coalitions. The second assumption of the Commission is that multi-ethnic government has to come about through the choice and decisions of political parties, rather than be constitutionally required or mandated. However, it realised that a multi-ethnic government was unlikely to come about purely through voluntary means. Consequently, it was willing to skew the electoral system in favour of 
multi-ethnic government by creating incentives for parties to seek cooperation with other parties, especially across racial boundaries. Its preference for voluntary over constitutionally mandated multiethnic government was motivated by its assessment that, in so far as a multi-ethnic government would arise out of a coalition, it needed a stronger foundation than a post-election pact-as such coalitions tend to be unstable. Of course in so far as a coalition is mandated by the constitution, it has greater prospects of survival than a purely voluntary arrangement, but the Commission may have been concerned about the deadlocks that may ensue from such a 'forced marriage', and the consequent delays in decision-making and administrative inefficiencies (Fiji CRC 1996:20, 279). The Commission had great faith in the capacity of political parties to respond to electoral incentives and to negotiate and fashion deals. It stated that 'the party system is deeply embedded in the [Fiji] political culture. Power-sharing should be achieved through the voluntary cooperation of political parties, or increased support for a genuinely multi-ethnic party' (Fiji CRC 1996:19). The Commission was therefore concerned to devise an electoral scheme in which the prospects for the formation and stability of multi-ethnic coalitions or the development of multi-ethnic parties would be high.

The key to that scheme was the electoral system. The Commission believed that it would be impossible to establish multi-ethnic government unless there was a change in the electoral system. The electoral system had to create incentives for cooperation among ethnic parties or lead to the formation of ethnic parties (Fiji CRC 1996:279). Essential to that purpose was the abolition of communal representation which had led to ethnic parties and prevented cooperation among them (Fiji CRC 1996:19-20, 279). However, the Commission recognised that it was unrealistic to expect at this stage to do away altogether with communal representation. The Commission's recommendations on the allocation of seats were a compromise between its preferred policy of no communal seats and the reality in which most parties supported or were willing to accept some communal representation, and that of the ruling SVT party which opposed any form of non-communal seats.

There are two elements to the Commission's proposals for the electoral system. The first relates to the allocation of seats in the House of Representatives. It recommended that in a House of 70 
seats, there should be 25 communal seats and 45 non-communal ('open seats'). The communal seats would be distributed as follows: Fijians (including Pacific islanders) 12; Indo-Fijians 10; General Voters 2 and Rotumans 1 . The crucial part of the recommendations was the system of constituencies and of voting for the open seats. The Commission recommended single-member constituencies for communal seats, and three-member constituencies for the open seats. The reason for choosing three-member constituencies will become apparent after the system of voting is explained.

For both types of seats, the system recommended for voting.was the Alternative Vote (AV). This system of voting has been described elsewhere in this volume. The essence of this system is that a candidate has to obtain an absolute majority (rather than plurality) of votes to win the elections. Voters cast their votes among the candidates in an order of preference. In order to determine the winner, the first preferences of all the candidates are counted to begin with. If a candidate obtains an absolute majority, he or she is declared elected, but if no one has enough votes, the candidate at the bottom is eliminated, and the second preferences of the voters of those voted for such a candidate are distributed accordingly among the remaining candidates. The process of elimination and redistribution is carried on until a candidate obtains the majority.

This system is used in single-member constituencies in preference to plurality voting in order to ensure that the winning candidate enjoys the support of the majority of voters. The system has the effect of encouraging parties and candidates to broaden their appeal to their electorates. If an electorate consists of two or more ethnic communities (none of which is in a majority), the chances are that the candidate who appeals to and beyond his or her community would win. This may also lead to cooperation among parties (especially in agreeing to urge their members to cast their second preferences for the candidates of their 'partner' parties). It may even lead to multiethnic parties. In communal seats the system would of course not work like this. Therefore the importance of AV for the purposes of the Commission lay in open electorates. However, if constituencies for open seats tended to have a clear majority of one community, AV would not work in the way desired by the Commission. Fearful that single-member constituencies would indeed be of this kind, the Commission recommended that open seats be contested in three- 
member constituencies to increase the likelihood of their being significantly ethnically heterogeneous, so that no one party could expect to win the elections on the strength of the votes of one community only. However, the Commission failed to explain clearly what the system of voting within the constituencies would be. The impression being that there would be one composite constituency, returning three candidates, as the Commission specified that the first, second and third preferences given to each candidate would be added together before the elimination of the candidate with the lowest votes (Fiji CRC 1996:329).

There was considerable confusion among the readers of the recommendations as to how precisely the elections for open electorates would be conducted. This was one of the major reasons that almost all political parties (and other commentators) were critical of the proposals. The system of AV is associated with singlemember constituencies - the consequences of its adoption in threemember seats were uncertain, and could indeed act to operate against minorities.

\section{A critique of the Commission's recommendations}

The impact of the recommendations was undoubtedly dented by the confusion about the method of voting proposed for open seats. It was impossible for political parties to establish how votes would be cast or its consequences, or how they might affect their strategies for political organisation or cooperation with other groups. Not surprisingly, they tended to disregard the recommendations. It is not my purpose to comment on the recommendations from the point of view of the mechanics of the recommendations or the feasibility of their implementation. I wish to examine some of the assumptions of the recommendations instead.

The Commission was at one with most parties and individuals who made representations to it on the necessity of multi-ethnic government. It departed from them in two important respects. First, its commitment to the Westminster system meant that it was not always prepared to accept the logic of some proposals for powersharing made to it, which implied a significant modification of that system. It would have been difficult for the Commission to take on the Westminster model in the absence of any large-scale opposition to it, but it is unfortunate that it did not examine (but assumed) that the 
model had worked well in the South Pacific. In fact it has not worked well and many problems such as the lack of political stability, incoherent policymaking, and a large measure of corruption in public life, can be attributed to it (Chan 1988; Ghai 1988, 1997). In any event, the Commission could have made more of an attempt to recommend modifications of the Westminster system in order to accommodate the general support of multi-ethnic governments expressed in most of the submissions to it. It was also mistaken in its observation that those supporting power-sharing had not tried to fit it within the Westminster model. In fact the NFP-FLP had gone to considerable lengths to examine and deal with some of the issues that might arise from its accommodation within Westminster.

The more important departure, partly (but only secondarily) aimed at preserving the 'purity' of Westminster, was in the method advocated to achieve multi-ethnic government. Most proposals assumed that political parties represented in the legislature would qualify for the membership of the cabinet in some proportion to their parliamentary seats. Most of them also specified the ethnic proportions that must be represented in the government. The Commission opposed this method, arguing that there was no realistic prospect of multi-ethnic government unless there are strong incentives within the electoral system for cooperation within what, for the time being, would continue to be mainly ethnic parties (Fiji CRC 1996:20). It was also influenced by the view that such coalitions, formed after elections, tend to be unstable. It supported a system which would lead to cooperation or partnership between political or ethnic groups before the elections-in fact, would constitute an essential element in their election strategy. For this reason it focused instead on the electoral system and came up with the specificities that I discussed above. It wanted the electoral system itself to provide incentives for cooperation between ethnically-based parties or preferably the formation of inter-ethnic parties. The success of this strategy depended on various assumptions that the Commission made. I argue that several of these assumptions were unjustified.

It was central to the recommendations of the Commission that parties are well established in Fiji and that they are able to take advantage of incentives offered by electoral rules. It is true that for a long period politics in Fiji were dominated by parties, with two large and relatively well-organised parties. However, the situation 
changed with the formation of the Fiji Labour Party. Its major impact was on Indo-Fijian politics and party organisation. The coups of 1987 and the promulgation of the 1990 Constitution had an equally significant impact on political organisation among the Fijian community, with the SVT replacing the Alliance as the dominant party. Its claim as the party of the chiefs and its close links with the Council of Chiefs affected the configuration of party organisation among indigenous Fijians. It was neither as well organised or representative as the Alliance. Since these developments, parties have been less firmly anchored among their supporters and there is considerable fluidity in their membership and leadership.

Another precondition for the success of the scheme recommended by the Commission is that there should be two or more parties in each community. This would facilitate cooperation or alliances between parties with different ethnic bases for the purpose of trading or polling votes. One could say that the existence of multi-parties in each of the major communities is an essential condition for the achievement of the goals of the Commission. It may be questioned whether the communities would remain politically divided. There was some incentive under the 1970 Constitution for the existence of more than one party in each community due to the existence of national seats. The community which dominated in a constituency could effectively determine the results of the election to the national seats, and each party had an incentive to field candidates for all national seats. So there was a role for a minority party within each community and, indeed, for multi-ethnic parties. However, the sense of communal competition for power so dominated the political system that, effectively, each community had one party only.

The situation changed under the 1990 Constitution for two reasons. The first was the abolition of national seats. The second, more important, was the provision of a built-in Fijian majority representation and domination. Not only did each community become inward-looking (under a system where there were only communal seats), but the huge Fijian majority representation eliminated a sense of competition for power from other communities. Consequently there emerged different claimants to power in the Fijian community, while the pre-coup divisions within the IndoFijians consolidated with the disappearance of the coalition that had 
formed government under Bavadra. It is likely that with the introduction of open seats, which would be the key determinants of access to power under the recommendations of the Commission, the sense of communal rivalry would re-emerge. It is hard to predict its effect on the pattern of party organisation. I want merely to suggest that the solidity within each community, especially the indigenous Fijians, is at least as likely as bifurcation or the emergence of multiethnic parties. It is conceivable that the Council of Chiefs or provincial councils would attempt to close Fijian ranks (just as there may be 'fundamentalists' among the Indo-Fijians). Ironically, it was the existence of a system in which seats were contested purely on a communal basis that produced divisions within each community, and created the situation which the Commission perceives is essential to the success of its proposals rejecting the dominance of communal seats.

A further assumption is that parties have effective control over their supporters and can direct them on how to cast their preferences. It remains to be seen whether voters would overcome a natural tendency to favour candidates of their own ethnic affiliation. The more complex the system of seats and voting, the less likely is it that voters would understand the implications of multi-ethnic cooperation. In this respect the continued existence of communal seats might work against the logic of open seats. It is possible that given a majority of communal seats, the tendency towards internal communal divisions may persist. There is therefore considerable irony that the effective working of the recommendations of the Commission in favour of open seats would depend on the logic of communal seats!

Yet a further assumption is the feasibility of the ethnic heterogeneity of constituencies. The Commission realised that a deliberate act of 'gerrymandering' would be necessary to establish heterogenous constituencies-and that such heterogeneity would be difficult in single-member constituencies. There are very considerable dangers in a deliberate design of constituencies. It would tend to politicise the process of their delimitation, which fortunately has been avoided hitherto. It would be most undesirable if the neutrality of the Constituency Boundaries Commission were undermined. 


\section{Conclusions}

I do not want to suggest that the scheme proposed by the Commission would not work in the way the Commission expects it to. I want to suggest that it may not work like that. There are too many assumptions and uncertainties about the system. If so, we have to assess whether it is desirable to put all one's eggs of multi-ethnic government in the electoral basket. The Commission's agenda is bold and eminently sensible and desirable-if it works. The negative side is that if it does not, the prospects for multi-ethnic government may become even more remote. The impression one gets on reading the $\mathrm{CRC}$ report is that it has made what one might call doctrinal objection to post-election coalition. In the search for its alternative proposals, it paid insufficient attention to the proposals for a constitutionally mandated power-sharing (even on a temporary basis). There is no doubt that the political integration through the electoral process that the Commission envisages is better than the alternatives it rejected-if it works. However, a close analysis of the NFP-FLP proposals (which the Commission does not undertake in its report, although it may have in its internal deliberations) would have demonstrated that the primary concern is integration through the political process.

In the end the choice may lie between a constitutionally mandated power-sharing, hopefully on terms that would encourage multiethnic parties, and a system which relies only on the electoral system to achieve that goal. In the realities of Fiji, the Commission may have underestimated the difficulties of persuading political parties and communities, particularly but not only Fijians, to move away from the essentials of the old system of representation. By placing so much weight on an untried electoral system (and it must be remembered that it is untried anywhere else, not only in Fiji), it has provoked acute anxieties about the electoral system. The Commission thereby gave up an immediately more feasible alternative-that of a constitutional mandate. Ironically, the provision of constitutionally mandated power-sharing would have facilitated agreement on the electoral system that the Commission has recommended. Perhaps in the end the Commission was too much influenced by textbook arguments against coalitions, and an unspoken prejudice against consociationalism-notwithstanding that its other recommendations 
are replete with the consociationalism of Fiji's past. However, even if they are not accepted, the Commission's bold and innovative approach and recommendations have opened up a lively debateand concentrated the minds of decision-makers in their search for multi-ethnic government.

\section{References}

Chan, Sir Julius, 1988. 'Experience with Papua New Guinea's Constitution: a Prime Minister's Reflections,' in Ghai, Yash (ed.), Law, Politics and Government in the Pacific Island States, Institute of Pacific Studies, Suva.

Ghai, Yash, 1997. 'Establishing a Liberal Political Order Through a Constitution: the Papua New Guinea experience,' Development and Change 28:303-30.

Ghai, Yash, 1988a. 'Political Consequences of Constitutions', in Ghai, Yash (ed.), Law, Politics and Government in the Pacific Island States, Institute of Pacific Studies, Suva.

Ghai, Yash (ed.), 1988b. Law, Politics and Government in the Pacific Island States, Institute of Pacific Studies, Suva.

National Federation Party and the Fiji Labour Party (NFP-FLP), 1995. Towards Racial Harmony and National Unity, Submission of NFP-FLP, Suva.

Soqosoqo ni Vakavulewa ni Taukei (SVT), 1995. Respect and Understanding: Fijian sovereignty, the recipe for peace, stability and progress, submission by the SVT, Suva. 